\title{
Media Sosial Instagram Sebagai Media Informasi Edukasi Parenting
}

\author{
Dian Nurvita Sari ${ }^{1^{*}}$, Abdul Basit ${ }^{2}$ \\ ${ }^{\text {I} P r o g r a m ~ S t u d i ~ M a g i s t e r ~ I l m u ~ K o m u n i k a s i ~ U n i v e r s i t a s ~ M e r c u ~ B u a n a ~ J a k a r t a ~}$ \\ Jln. Meruya Selatan No.31, RW.1, Meruya Sel., Kec. Kembangan, Kota Jakarta Barat, \\ Daerah Khusus Ibukota Jakarta 1161, Indonesia \\ *Koresponden : diannurvitasari25@gmail.com \\ ${ }^{2}$ Prodi Ilmu Komunikasi FISIP Universitas Muhammadiyah Tangerang \\ Jl. Mayjen Sutoyo No. 2, Kota Tangerang, Banten, Indonesia \\ Koresponden :basit.umt@gmail.com
}

\begin{abstract}
Abstrak
Fenomena penggunaan media sosial sebagai media edukasi parenting dikalangan ibu muda tak lepas dari kemajuan teknologi yang diiringi dengan kemunculan internet. Sebelumnya para ibu muda akan berorientasi kepada pengalaman orang tua terdahulu mengenai bagaimana cara mengasuh, meraw at dan mendidik anak-anak mereka. Kini informasi edukasi mengenai parenting telah mengalami pergeseran bukan lagi dengan media offline namun telah mengarah pada platform online.Penelitian ini menggunakan metode penelitian kualitatif dengan pendekatan studi fenomenologi.Objek penelitian adalah follower akun instagram @ parentalk.id yang merupakan ibu muda. Sedangkan subjek dari penelitian adalah aliran informasi dalam implementasi new mediayakni postingan pada akun instagram @parentalk.id.Penggunaan media sosial Instagram sebagai media edukasi khususnya pembelajaran tentang parentinguntuk mencari informasi mengenai parentingoleh followers akun instagram @ parentalk.id ini menghasilkan sebuah respons kognitif (informasi), afektif (emosi) dan behavioral (tindakan) dalam mengakses, melihat, dan mencari postingan akun instagram @ parentalk.id.
\end{abstract}

Kata Kunci: Media Sosial, Instagram, Edukasi Parenting

\begin{abstract}
The phenomenon of the use of social media as a parenting education media among young mothers cannot be separated from technological advancements accompanied by the emergence of the internet. Previously, young mothers will be oriented to the experience of past parents about how to care for, care for and educate their children. Now educational information about parenting has undergone a shift no longer with offline media but has led to online platforms. This study uses qualitative research methods with a phenomenological study approach. The object of research is the follower @ parentalk.id Instagram account which is a young mother. While the subject of the research is the flow of information in the implementation of new media, namely posting on the Instagram account @ parentalk.id. The use of Instagram social media as an educational medium, especially learning about parenting to find information about parenting by followers of Instagram @ parentalk.id accounts produces a cognitive response (information), affective (emotion) and behavioral (action) in accessing, viewing, and looking for posts Instagram account @ parentalk.id.
\end{abstract}

Keywords: Social Media, Instagram, Edukasi Parenting

\section{PENDAHULUAN}

Sebuah survei global pada pengguna internet pada tahun 2017 melaporkan bahwa jumlahpengguna smartphone telahtumbuh pada tingkat yang menakjubkan(Huang and $\mathrm{Su}$ 2018). Saat ini, lebih dari setengah populasi dunia memiliki smartphone. Masyarakat umum menjadi sangat tergantung pada smartphone.Jumlah rata-rata waktu yang dihabiskan orang dewasa untuk smartphone-nya per hari melonjak dari 15 menit pada 2008 menjadi 2 jam dan 48 menit pada 2015 (Jackson et al. 2013). Di era globalisasi saat ini media massa mempunyai 
DOI: $10.30596 /$ persepsi.v\%vi\% i.4428

peranan penting dalam membentuk pola hidup masyarakat. Media menjadi patokan bagi masyarakat untuk mendapatkan informasi, terutama bagi masyarakat informasi, mereka dengan mudah dapat mengakses segala informasi yang mereka butuhkan.Kehadiran media massa telah bertransformasi, sehingga kini masyarakat dapat mengakses informasi dari media massa melalui smartphone yang ditunjang dengan akses internet.

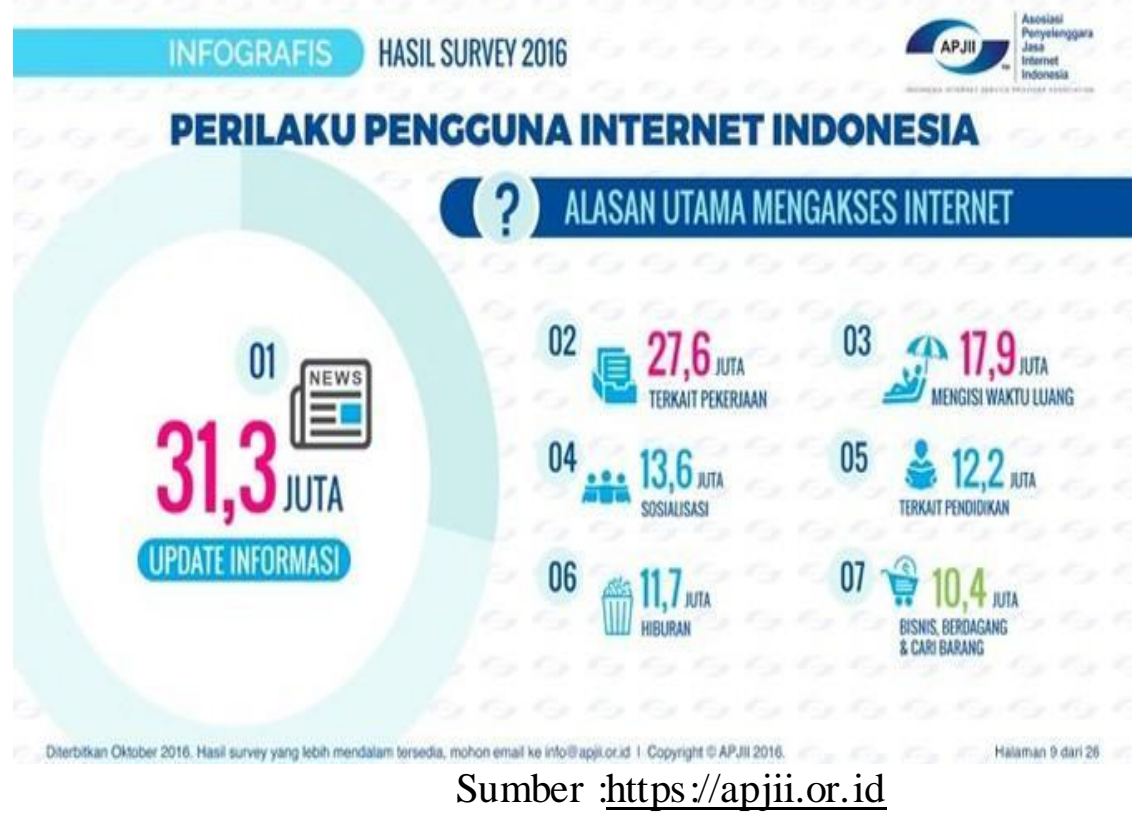

Menurut survei Asosiasi Penyelenggara Jasa Internet Indonesia (APJII) terkait Penetrasi dan Perilaku Pengguna Internet Indonesia 2016, sebanyak 31,3 juta (25,3\%) orang mengakses internet untuk update informasi, baik melalui berita maupun lainnya.Keadaan dimana masyarakat sangat bergantung pada informasi menjadikan masyarakat sebagai Information society atau masyarakat informasi adalah sebuah istilah yang digunakan untuk mendeskrips ikan sebuah masyarakat dan sebuah ekonomi yang dapat membuat kemungkinan terbaik dalam menggunakan informasi dan teknologi komunikasi baru (New Information and Communication Technologies (ICT's)).

Informasi saat ini bisa mendapatkan keuntungan yang penuh dari teknologi baru dalam segala aspek kehidupan; di tempat kerja, di rumah dan tempat bermain. Contoh dari ICT's adalah ATM untuk penarikan tunai dan pelayan perbankan lainnya, telepon genggam (handphone), teletext television, faxes dan pelayan informasi seperti internet, e-mail, mailinglist, serta komunitas maya (virtual community) dan lain-lainnya. Jadi dapat dikatakan bahwa pengolahan informasi adalah inti dari kegiatan. Masyarakat informasi yang berkelanjutan adalah masyarakat yang me manfaatkan Teknologi dan pengetahuan sangat baik dalam kehidupan seluruh umat manusia pada generasi sekarang dan yang akan datang, dengan memperkuat keanekaragaman hayati, pengunaan teknologi, kekayaan ekonomi, serta partisipasi dalam semua aspek politik.Kearifan budayabaru ini memiliki implikasi untuk segala aspek dari masyarakat dan untuk kegiatan ekonomi, teknologi mengubah cara seseorang melakukan bisnis, bagaimana cara seseorang belajar, bagaimana menggunakan waktu luang dan lain sebagainya(Røpke 2009).

Kehadiran Internet bisa dibilang terlambat di Indonesia, namun perkembangannya pun sangat cepat.Pada awalnya Internet hanya tersedia di media komputer, namun saat ini sudah ada di media elektronik yang kita bisa bawa kemana mana seperti tablet, laptop dan handphone. Saat ini media media konvensional seperti televisi, radio dan koran telah dikesampingkan oleh masyarakat di dunia, termasuk di Indonesia. Media konvensional ini 
telah tergantikan oleh Internet. Hampir seluruh kegiatan manusia memanfaatkan kecanggihan teknologi informasi. Perkembangan teknologi informasi memunculkan berbagai jenis kegiatan yang berbasis pada teknologi informasi, seperti e-government, e-commerce, eeducation dan lainnya(Gumilar et al. 2014). Dua fungsi utama dalam melakukan komunikasi melalui media massa tersebut banyak digunakan oleh sektor industri, terutama untuk menyebarkan informasi dan melakukan promosi mengenai industri mereka(Gumilar et al. 2014). Perkembangan teknologi informasi komunikasi saat ini semakin memberikan kemudahan bagi masyarakat didalam mendapatkan kebutuhan akan informasi.

Salah satu teknologi informasi komunikasi yang semakin banyak digunakan saat ini adalah media sosial Instagram. Instagram adalah bentuk komunikasi yang relatif baru yang dimanapengguna dapat dengan mudah membagikan informasi berupa photo atau video yang disebut dengan "updates" (Hu, Manikonda, and Kambhampati 2014). Mudahnya cara penggunaan aplikasi Instagram membuat pengguna menjadikan Instagram sebagai media informasi untuk memenuhi kebutuhannya. Penggunaan instagram sebagai media informasi edukasi merupakan suatu fenomena baru yang ada di dalam penggunaan media social, bahkan media sosial terus tumbuh dan sangat lazim di kalangan orang anak muda sekarang ini (Pittman and Reich 2016).

Pengetahuan pengasuhan anak sebaiknya dimiliki oleh orang tua agar dapat mengasuh anak lebih baik dan menunjang pertumbuhan dan perkembangan anak(Asiodu et al. 2015). Namun, pada kenyataanya tidak semua orang tua memiliki pengetahuan dan keterampilan yang memadai mengenai pengasuhan anak(Churchill and Clarke 2010). Minimnya pengetahuan dan keterampilan orang tua mengenai pengasuhan dapat menimbulkan perlakuan salah pada anak(Baker, Sanders, and Morawska 2017).Fenomena penggunaan media sosial sebagai media edukasi parentingdikalangan ibu muda tak lepas dari kemajuan teknologi yang diiringi dengan kemunculan internet. Media sosial adalah kendaraan penting untuk menyebarkan informasi dan pola pengasuhan anak untuk pendidikan dan dukungan sosial, informasi parentingdan pengasuhan anak(Asiodu et al. 2015; Haslam, Tee, and Baker 2017).

Saat ini, melalui smarthphone siapa saja dapat mengakses informasi apapun termasuk para ibu muda yang dapat dengan mudah mengakses informasi mengenai parenting melalui media social(Simps on 1997).Para ibu sangat terlibat dalam media sosial, 81\% orang tua yang menggunakan media sosial mencoba menanggapi kabar baik yang dibagikan orang lain di jaringan mereka, termasuk $45 \%$ orang tua yang menggunakan media sosial yang "sangat setuju" bahwa mereka melakukannya(Duggan et al. 2015). Sebelumnya para ibu muda atau mereka yang baru memiliki seorang anak akan berorientasi kepada pengalaman orang tua terdahulu mengenai bagaimana cara mengasuh, merawat dan mendidik anak-anak mereka. Kini informasi edukasi mengenai parenting telah mengalami pergeseran bukan lagi dengan media offline namun telah mengarah pada platform online diantaranya media sosial. Kini pertukaran informasi mengenai parenting tidak lagi terbatasi oleh ruang dan waktu.Mendapatkan informasi dan saran spesifik adalah alasan utama orang tua mengakses media sosial untuk tujuan pengasuhan anak(Has lam et al. 2017).

\section{Internet}

Afriani (2011) mengatakan internet merupakan jaringan longgar dari ribuan jaringan komputer yang menjangkau jutaan orang di seluruh dunia.Misi awalnya adalah menyediakan sarana bagi para peneliti untuk mengakses data dari sejumlah komputer. Namun sekarang internet telah berkembang menjadi ajang komunikasi yang sangat efektif, sehingga telah menyimpang jauh dari misi awa lnya (Kurniawan 2017).

Dengan demikian Internet adalah suatu jaringan komputer ang memungkinkan terjadinya komunikasi interaktif didalamnya, dimana jutaan orang di dunia dapat terhubung 
Vol 3No. 1, 2020, 23-36

DOI: $10.30596 /$ persepsi.v\%vi\% i.4428

menjadi suatu komunitas baru dalam jaringan multimedia tersebut tanpa dibatasi ruang dan waktu. Penggunaan internet untuk bisnis secara online telah tumbuh dengan pesatnya. Total nilai perdagangan barang dan jasa dunia melalui ecommerce mencapai $\$ 4,3$ trilliun pada tahun 2004. Tingkat pertumbuhan perdagangan via internet dari tahun 2001 hingga 2005 mencapai 68\% di Amerika Serikat, Eropa 91\%, dan Asia 109\%. Menariknya, 85\% dari perusahaan yang melibatkan perdagangan online tersebut adalah usaha berskala kecil dan menengah (Celuch, Goodwin, and Taylor 2007).

\section{Media Sosial}

Media sosial adalah sebuah media online dimana para penggunanya bisa dengan mudah berpartisipasi, berbagi, dan menciptakan isi meliputi blog, sosial network atau jejaring sosial, wiki, forum dan dunia virtual. Blog, jejaring sosial dan wiki mungkin merupakan bentuk media sosial yang paling umum digunakan oleh masyarakat di seluruh dunia(Kurniawan 2017). Media sosial online merupakan media yang didesain untuk memudahkan interaksi sosial bersifat interaktif dengan berbasis teknologi internet yang mengubah pola penyebaran informasi dari sebelumnya bersifat broadcast media monologue (satu ke banyak audiens) ke media sosial dialogue (banyak audiens ke banyak audiens). Jenis serta kompos isi media sosial online di dunia virtual sangat beragam, antara lain jejaring sosial (Facebook, Instagram, Friendster, Linkedln, dan sebagainya), microblogging platform (Twitter, Plurk, Koprol, dan la in-lain), jejaring berbagi foto serta video (Flickr, Youtube, dan sebagainya), Podcast, Chat rooms, Message board, Forum, Mailing list, serta mas ih banyak lainnya.

Berdasarkan Literasi Uses and grativication McQuail, empat tujuan berbeda dalam menggunakan media - pencarian informasi, identitas pribadi, interaksi sosial \& integrasi, dan hiburan(Kim, Sin, and He 2013). Sebagian besar platform media sosial digunakanuntuk mencari informasi. Media sosial adalah medium di internet yang memungkinkan pengguna merepresentasikan dirinya maupun berinteraksi, bekerja sama, berbagi, berkomunikasi dengan pengguna lain, dan membentuk ikatan sosial secara virtual (Sari Puspita 2017).

Media sosial mengacu pada penggunaan teknologi berbasis web dan seluler untuk mengubah komunikasi menjadidialog interaktif. Media sosial mengambil berbagai bentuk media termasuk majalah, forum internet, blog, blog sosial, microblogging, wiki, podcast, foto atau gambar, video, peringkat dan bookmark sosial. Dengan dunia di tengah-tengah revolusi media sosial, lebih dari jelas bahwa media sosial seperti facebook, twitter, instagram dll, digunakan secara luas untuk tujuan komunikasi. Bentuk komunikasi ini dapat dengan seseorang atau sekelompok orang. Saat ini sebagian besar orang khususnya anak-anak itu terhubung ke media sosial yang berbeda untuk tetap berhubungan dengan teman sebaya mereka. Media sosial digunakan untuk interaksi sosial sebagai superset di luar komunikasi sosial.

Keluwesan media sosial berhubungan dengan pemanfaatan penggunaan yang semakin mudah.Setiap orang tanpa kesulitan dapat menggunakan media sosial untuk mencari, memperoleh dan memanfaatan informasi yang beragam dalam koridor kebebasan berkomunikasi.Media sosial sebagai entitas pengolah dan penyebar informasi yang fleksibel dimanfaatkan oleh pengguna yang tidak tersegmentasi dalam kelompok sosial, ekonomi dan politik.Fleksibilitas media sosial mampu membangun dan meningkatkan hubungan antar individu maupun kelompok di dunia maya, yang tidak dibatasi oleh perbedaan status di masyarakat.

Perkembangan media sosial saat ini semakin memberikan kemudahan bagi masyarakat didalam mendapatkan kebutuhan akan informasi. Salah satu media sosial yang semakin banyak digunakan saat ini adalah media sosial Instagram. 
Vol 3No. 1, 2020, 23-36

DOI: $10.30596 /$ persepsi.v\%vi\% i.4428

\section{Teori Uses and Gratification}

Pada kajian komunikasi ada sebuah teori yang bernama uses and gratification, Teori ini pertama kali dikenalkan oleh Harbert Blumer dan Elihu Katz (1974). Teori ini membahas bahwa pengguna media memainkan peran aktif untuk memilih dan menggunakan media tersebut. Yang artinya, pengguna media adalah pihak yang aktif dalam proses komunikasi (Hidayat, 2006).

Teori uses and gratification adalah salah satu teori darikomunikasi yang berfokus pada komunikasi sosial. Te ori ini mengadaptasi fungsionalistikpendekatan komunikasi dan media, dan menyatakan bahwa peran paling penting media adalahmeme nuhi kebutuhan dan motivasi audiens. Oleh karena itu, semakin banyak kebutuhan ini terpenuhi, makalebih banyak kepuasan dihasilkan(Mehrad and Tajer 2016). Teori ini awalnya berfokus pada motif penonton dan kemudian menganalis is pesan dan sistem sosial (Mehrad and Tajer 2016). Dengan kata lain, teori ini berkonsentrasi pada bagaimana pengguna mencari media dan sejauh mana merekapuas dengan jenis, konten, dan metode penggunaannya.

Dalam ranah digital ini, banyak manfaat dan kemudahan bagi pengguna teknologi untuk mengakses informasi, pengetahuan, dan rujukan mereka untuk memilih media dalam satu alat, yang ada di tangan mereka, dapat memberikan manfaat dan menggabungkan berbagai platform informasi sehigga menjadi lebih mudah. Kelebihan fitur Instagram de ngan postingan photo, video live, comment, direct massage dapat dengan mudah digunakan oleh followers dalam berkomunikasi baik kepada pemilik akun atau admin atau kepada sesame followers akun Instagram.

\section{Motivasi Pe nggunaan Instagram}

Motif adalah orientasi umum yang mempengaruhi tindakan orang untuk memuaskanke inginan dan kebutuhan mereka (Study 2006). Pencarian informasi, komunikasi interpersonal (utilitas interpersonal), ekspresi diridan motif melarikan diri diadopsi dalam studi saat ini, karena keempat motif iniadalah yang paling akrab dalam menje laskan penggunaan situs je jaring sosial. Informasimencari (kognitif) motif berarti memperoleh atau mencari informasi melalui SNS. Itumotif komunikasi interpersonal, juga dikenal sebagai motif hubungan sosial,menyiratkan orientasi interaksi sosial serta pemeliharaan hubungan dengan orang lain. Ketiga, motif ekspresi diri didefinisikan sebagai tampilan gambar pribadi danidentitas menggunakan SNS, dengan kata lain, tujuan menggunakan SNS adalah untuk menyampaikan diri,termasuk hobi, minat, ide dan perasaan, kepada orang lain. Akhirnya, pelarianMotif memungkinkan orang untuk menjauh dari realitas dan kesepian mereka, melupakan merekamasalah atau kekhawatiran sementara saat menggunakan SNS.

Penggunaan media sosial Instagram sebagai media edukasikhususnya pembelajaran tentang parentinguntuk mencari informasioleh followers akun instagram @ parentalk.idini menghasilkan sebuah respons kognitif (informasi), afektif (emosi) dan behavioral (tindakan) dalam mengakses, melihat, dan mencari postingan akun instagram @ parentalk.id. 
Vol 3No. 1, 2020, 23-36

DOI: $10.30596 /$ persepsi.v\%vi\% i.4428

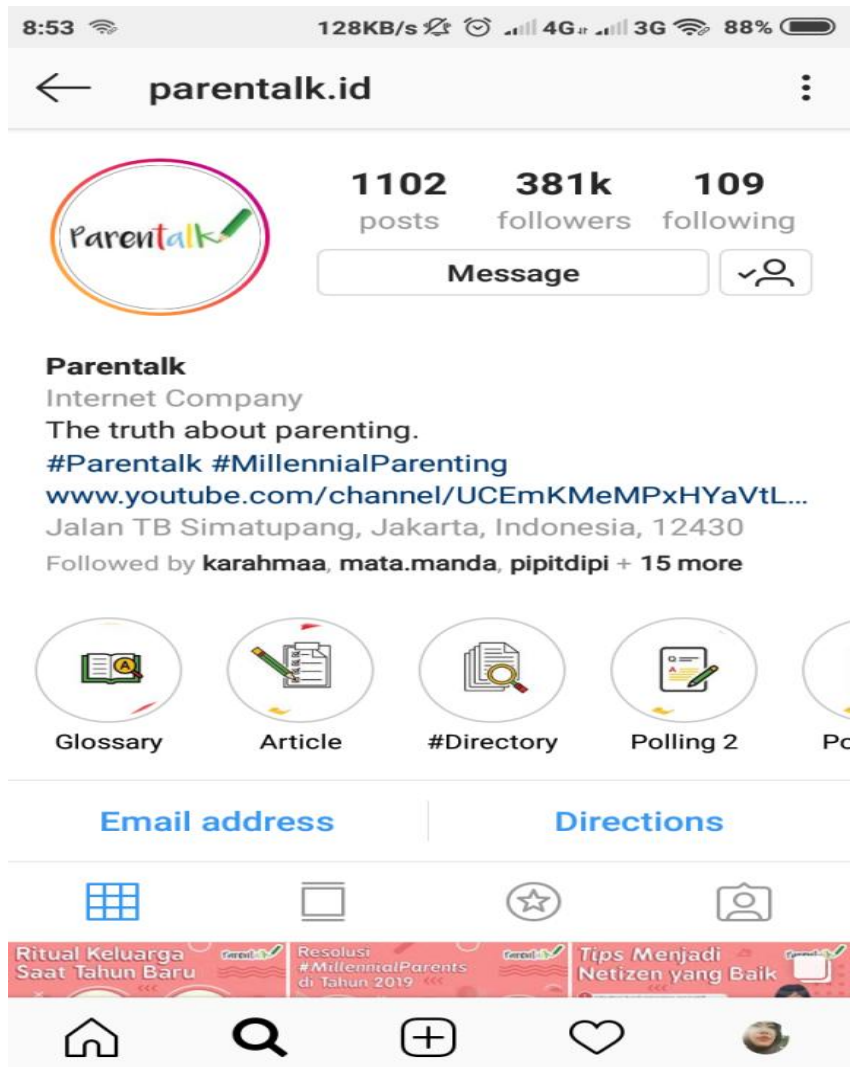

Gambar 1. Tampilan profile akun instagram @ parenttalk.id

Dari keterangan gambar 1 dapat kita lihat tampilan profile akun instagram @ parentalk.id yang memuat tentang bio dan data jumlah postingan serta jumlah followers. Akun instagram @ parentalk.id memiliki jumlah followers sebanyak 381 ribu dan telah memposting sebanyak 1.102 buah postingan berupa photo dan video.

Menurut Tarmuji dalam bukunya Apriastuti, 2013, parenting atau dikenal juga dengan istilah pola asuh adalah bentuk-bentuk yang diterapkan dalam rangka merawat, me melihara, membimbing dan melatih dan memberikan pengaruh yang dilakukan oleh orang tua kepada anaknya(Afrilia 2017).Parenting education menjelaskan berbagai program pengajaran dan dukungan yang fokus pada keterampilan, perasaan, dan tugas menjadi orangtua(Erlanti and Mulyana 2016). Hays (1996) dalam "Staying at Home" versus "Working": A Call for Broader Conceptualizations of Parenthood and Paid Work menjelaskan bahwa ideologi keibuan yang dominan di Amerika Serikat saat ini adalah "intensive mothering". Terdapat tiga syarat untuk memenuhi kriteria "intensive mothering", yang harus dipenuhi perempuan jika ingin disebut sebagai "ibu yang baik": (1) Pengasuhan anak merupakan tanggung jawab utama seorang ibu; (2) Pengasuhan anak harus bersifat "child-centered"; (3) Anak-anak tidak ternilai harganya, merupakan mahkluk suci yang tidak berdosa(Arindita 2017).

Melalui media sosial Instagram para ibu muda yang tergabung sebagai follower akun Instagram @parentalk.id dapat dengan mudah berkomunikasi bertukar informasi dan pengalaman mereka dalam hal parenting. Penelitian ini, peneliti mencoba menjawab pertanyaan mengenai bagaimana pemanfaatan akun instagram sebagai media edukasi khususnya edukasi parenting yang dilakukan oleh akun instagram @parentalk.id.Bahwa orang tua memang menggunakan media sosial untuk tujuan pengasuhan, dan bahwa itu dapat berfungsi sebagai jenis dukungan sosial(Haslam et al. 2017). 
Vol 3No. 1, 2020, 23-36

DOI: $10.30596 /$ persepsi.v\%vi\% i.4428

\section{METODE PENELITIAN}

Objek penelitian adalah follower akun instagram @ parentalk.id yang merupakan ibu muda. Sedangkan subjek dari penelitian adalah aliran informasi dalam implementasi new mediayakni postingan pada akun instagram @parentalk.id. Penelitian dengan observasi, wawancara secara mendalam dengan key informant, pengumpulan datahingga penyusunan laporan.Dalam penelitian ini peneliti menggunakan paradigma konstruktivisme. Konstruktivisme, menurut (Guba.1990) dalam Agus salim 2006 ada lah dimana pengetahuan merupakan hasil konstruksimanusia dan tidak pernah dipertanggungjawabkan sebagai kebenaran yang tetap, tetapimerupakan permasalahan yang selalu berubah. Dengan kata lain, aktivitas manusia merupakanaktivitas mengkontruksi realitas, dimana hasilnya tidak menjadi kebenaran yang tetap tetapisela lu berkembang terus.

Penelitian ini menggunakan metode penelitian kualitatif dengan pendekatan studi fenomenologi. Pene litian fenomenologi dimulai dengan menelaah fokus fenomena yang akan dite liti. Mencari pemahaman mendalam, serta berusaha memahami arti peristiwa dan kaitankaitannya terhadap orang-orang yang berada dalam situasi- situasi tertentu.Penelitian fenomenologi merupakan tindakan untuk menangkap pengertian sesuatu yang sedang dite liti.Sehingga, studi dengan pendekatan fenomenologi berupaya untuk menjelaskan makna pengalaman hidup sejumlah orang tentang suatu konsep atau gejala.

Observasi yang dilakukan oleh penulis berupa observasi partisipan, dimana penulis melakukan proses pengamatan dengan ikut menjadi bagian dalam kehidupan objek penelitian untuk mendapatkan hasil observasi yang akurat. Dalam penelitian ini, peneliti turut serta menfollow akun instagram @ parenttalk.id untuk mengamati secara langsung postingan yang dimiliki serta melihat respons followers lebih dekat.

\section{HASIL TEMUAN DAN PEMB AHASAN}

Hasil penelitian yang didapat oleh penulis dalam penelitian yang merupakan interpretasi dari hasil penelitian melalui teknik wawancara, observasi dan data dokumentasi ini didapat dari follower akun instagram @ parentalk.id.

Penulis melihat motifasi para followers dalam menggunakan akun instagram @ parentalk.id adalah untuk dijadikan sebagai rujukan dan referensi bagi followers khus unya hal-hal yang berkaitan dengan edukasi parenting.

Penulis melihat adanya tiga respons yang dihasilkan oleh followers akun instagram @ parentalk.id setelah melihat postingan yang berupa photo, photo video atau interaktif talk. Respons tersebut adalah respons kognitif, respons afektif dan respons behavioral. Respons diartikan sebagai suatu hasil atau akibat yang dikerjakan oleh seseorang yang menerima sebuah stimulus.Stimulus ini merupakan sesuatu yang dapat diterima seseorang me lalui alat inderanya.Terdapat tiga respons, yang dikemukakan oleh Steven M. Chaffee (Rakhmat, 1999) yang pertama adalah respons kognitif, berkaitan dengan pengetahuan, keterampilan dan informasi seseorang mengenai sesuatu yang timbul bila dipahami atau digambarkan oleh seseorang.Jadi respons kognitif diartikan juga sebagai respons yang membahas tentang sebuah kebiasaan dalam mencari berbagai pengetahuan dan informasi oleh seseorang mengenai sesuatu yang bisa membentuk suatu makna dan pandangan. Hal tersebut bila dikaitkan dengan kegiatan followers akun instagram @ parentalk.id yang mencari informasi parentingmelalui akun tersebut. Pemililihan media informasi edukasi saat ini sangat diperlukan.Pengguna media memiliki peran aktif untuk memilih dan menggunakan suatu media.Biasanya para pengguna mediamemilih suatu media karena kebutuhan secara psikologis dan sosial masing-masing. Sama halnya dengan yang dilakukan oleh informan, mereka memilih Instagram sebaga i perangkat media informasi edukasi karena pengaplikasian yang mudah(Haslam et al. 2017). 
Vol 3No. 1, 2020, 23-36

DOI: $10.30596 /$ persepsi.v\%vi\% i.4428

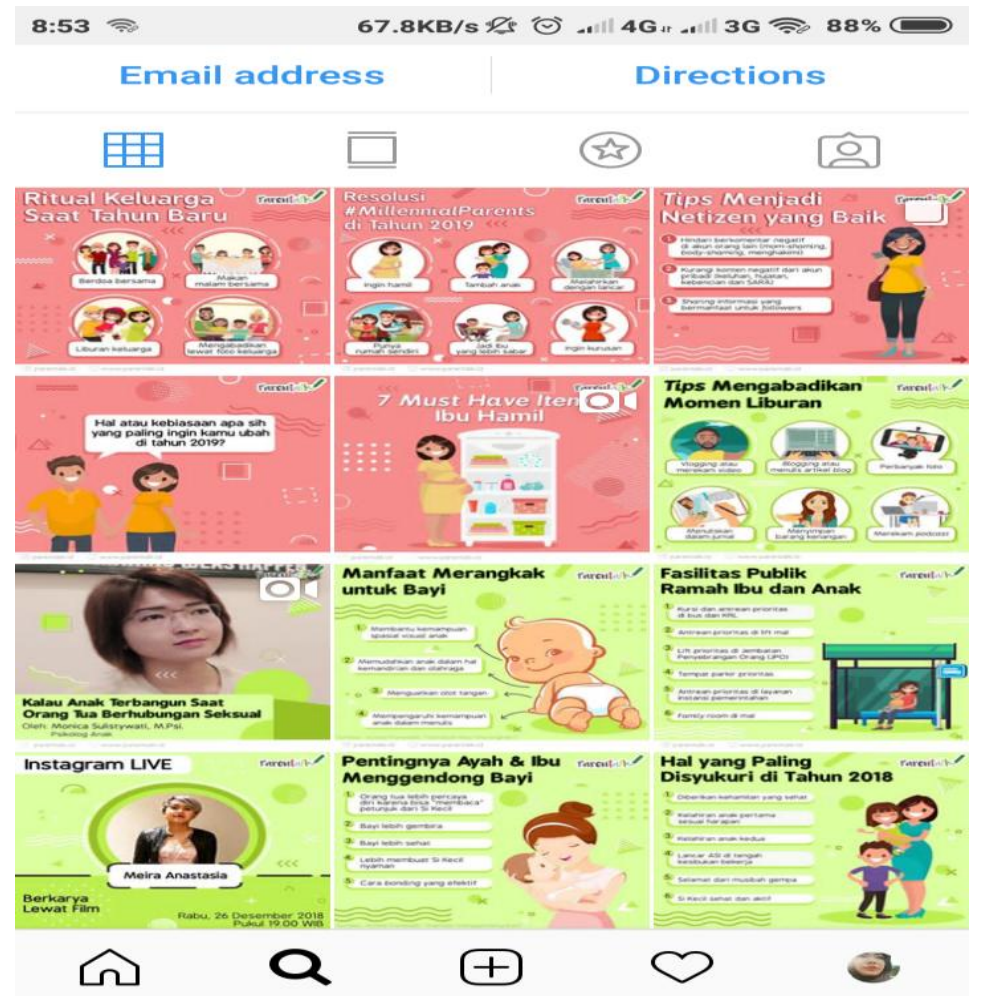

Gambar 2. Tampilan yang memuat postingan pada akun instagram @ parentalk.id

Dari gambar 2 dapat terlihat tampilang postingan pada laman akun instagram @ parentalk.id. Dari gambar tersebut dapat terlihat beberapa contoh postingan yang dimiliki oleh akun instagram @ paretalk.id yang memuat tentang informasi parenting. Postingan yang dimiliki bukan saja hanya berupa photo namun kerap kali admin memposting video berisi visul dan audio yang sangat berguna bagi para followers dalam pengaplikasian mengenai praktek pada topik yang sedang dibahas. Selain itu, admin pun kerap kali mengadakan siaran langsung interaktif talk bersama narasumber yang berkompeten pada bidang parenting. Melalui salah satu fasilitas instagram yang disebut "live" admin menampilkan interaktif talk secara langsung kemudian followers dapat memberikan pertanyaan yang akan secara langsung dijawab oleh narasumber berkaitan dengan te ma yang sedang dibahas.

Melalui berbagai fasilitas yang diberikan oleh media sosial instagram, akun @ parentalk.id menyajikan informasi edukasi parenting dengan berbagai bentuk postingan yang bervariasi.Dan diharapkan melalui pembacaan postingan tersebut mampu memberikan respons kognitif bagi followers yang merupakan ibu muda dalam edukasi parenting. Melalui wawancara kepada narasumber yang merupakan followers akun instagram @ parentalk.id, mereka merasakan adanya kemudahan untuk mengakses informasi terkait edukasi parenting sehingga dapat mereka jadikan sebagai referensi atau rujukan dalam mengasuh dan merawat anak-anak mereka(Asiodu et al. 2015).

Informan menyebutkan bahwa:

"Followers tertarik pada akun parenting ini karena kebutuhan informasi dalam mengurus anak. Selama ini cara mengurus anak berdasarkan ajaran dari leluhur, celakanya kalau kita ngadepin anak tetapi orangtua juga ga bisa kasih referensi penangan yang tepat bikin bingung harus gimana nagdepin anak.Akun Instagram @parentalk.id ini menarik memberi ruang bagi kami para ibu untuk mendapatkan informasi dalam parenting, selain 
Vol 3No. 1, 2020, 23-36

DOI: $10.30596 /$ persepsi.v\%vi\% i.4428

kita dapat informasi dari postingan kita bisa dapat informasi berdasarkan pengalaman dari followers yang lain"

(Wawancara@destibundaalbie sebagai followers@parentalk.id)

Respons yang kedua adalah afektif, respons ini adalah suatu perubahan dan pembentukan sikap seseorang yang melibatkan suatu rangsangan emosional atau mood, terdapat beberapa faktor yang memengaruhi intensitas rangsangan emosional, salah satunya adalah suasana emosional atau kondisi individu secara psikologis yang ada ketika ia mengkonsumsi media (Mutmainah and Fauzi 2002). Pada respons ini, penulis ingin mengetahui apakah followers setelah melihat postingan dari akun @ parentalk.id merasakan adanya rasa ketertarikan secara emosional.

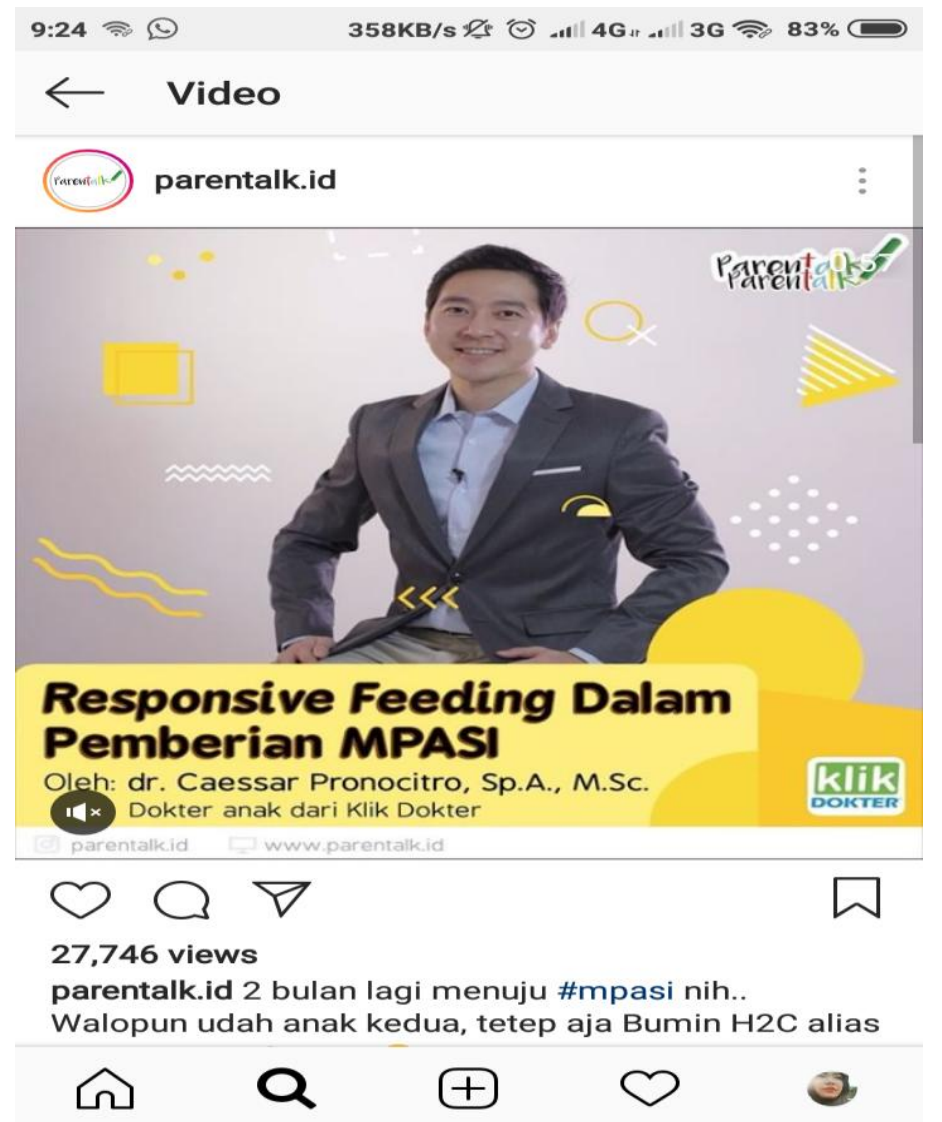

Gambar 3. Memuat Postingan video oleh nara sumber seorang dokter anak

Informan menyebutkanbahwa :

"Selain itu tampilan postingan harus menarik, photo atau video ditambahkan dengan caption yang semenarik mungkin untuk menarik perhatian followers sehingga followers berminat untuk memfollow. Caption tema dan narasumber dalam video menarik sehingga membuat followers memutar video tersebut. Pertama kan gituh harus suka dulu pada pandangan pertama, dilihat menarik baru cari tahu, merasa tertarik, ada manfaatnya ya langsung follow."

(Wawancara@destibundaalbie sebagai followers@parentalk.id)

Sikap emosional dan ketertarikan ditunjukkan oleh follower melalui respon mereka terhadap sebuah postingan di akun instagram @ parentalk.id. Respon yang mereka berikan berupa "like" photo atau video. Dalam gambar tersebut dapat kita lihat jumlah views menunjukkan sebanyak 27.746 kali video tersebut diputar. Ini menunjukkan adanya respon afektif ketertarikan secara emosional para followers untuk memutar vide o yang diposting oleh admin 
Vol 3No. 1, 2020, 23-36

DOI: $10.30596 /$ persepsi.v\%vi\% i.4428

pada akun instagram @parentalk.id. Tak jarang para followers menularkan ketertarikan mereka tehadap suatu postingan kepada pengguna instagram yang lain baik yang menjadi followers akun @ parentalk.id ataupun yang belum menjadi followers aktif. Caranya adalah dengan menautkan nama akun pengguna instagram lain pada kolom comment hal ini biasa disebut dengan istilah mention. Sehingga pengguna instagram lain yang nama akunnya dicantumkan pada kolom comment dapat melihat postingan yang ada pada akun @ parentalk.id. Biasanya mereka menautkan nama pengguna instagram lain yakni orangorang yang mereka kenal dan mereka anggap memiliki kesamaan dalam hal kebutuhan akan informasi edukasi parenting yang ada pada sebuah postingan. Sehingga dapat dipastikan mereka memiliki ketertarikan yang sma secara emosional untuk melihat postingan yang dimaksud(Pittman and Reich 2016).

Respons yang terakhir yaitu behavioral, respons ini adalah akibat yang ditimbulkan oleh diri khalayak yang membentuk sebuah perilaku, tindakan dan kegiatan. Terdapat dua efek media yang menghasilkan sebuah respons behavioral yaitu perilaku agresif yaitu kegiatan yang buruk bahkan merusak dan perilaku proposial atau kegiatan yang bersifat positif(Churchill and Clarke 2010; Mutmainah and Fauzi 2002). Pada kegiatan followers untuk mencari informasi edukasi parenting pada akun @parentalk.id, terdapat perilaku proposial atau adanya kegiatan postitif setelahmendapatkan informasi. Kegiatan ini merancu kepada hal yang menimbulkan keterampilan yang bermanfaat bagi dirinya sendiri bahkan untuk orang lain(Baker et al. 2017).

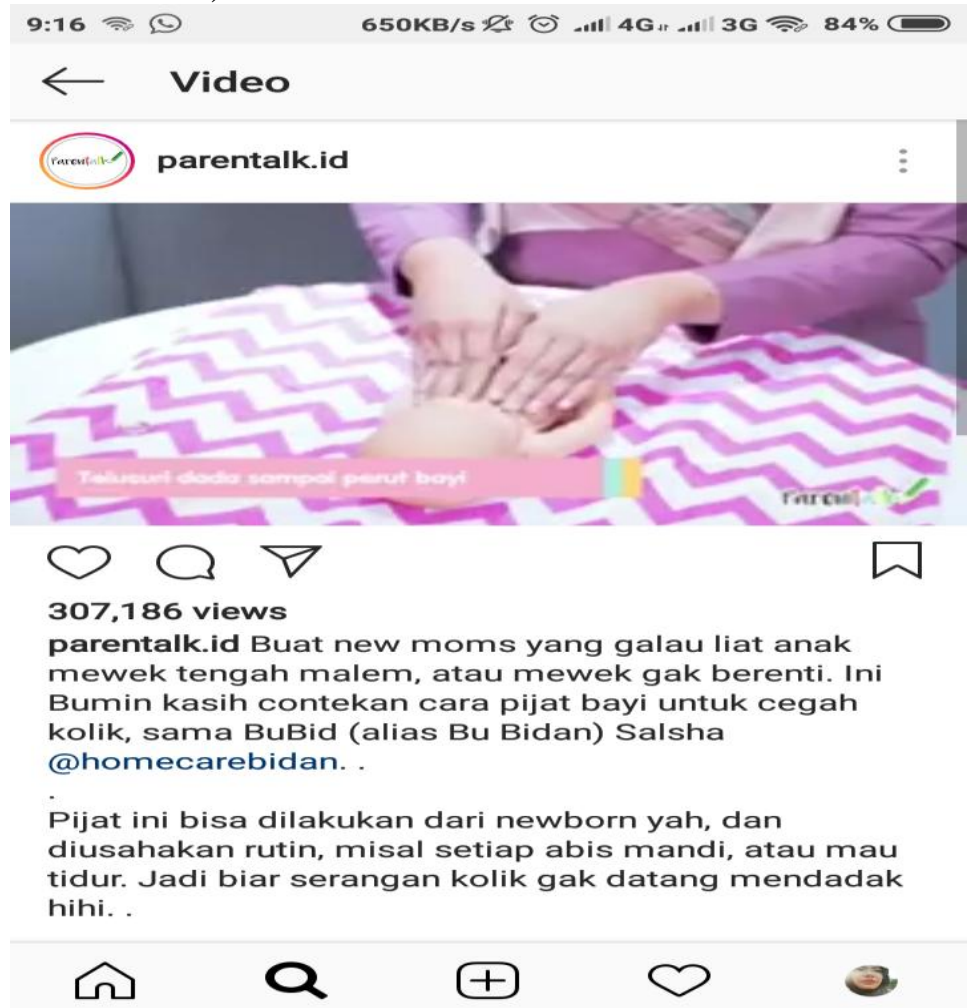

Gambar 4. Memuat postingan video cara pijat untuk bayi

Dari gambar 4 kita dapat melihat sebuah video cara pijat untuk bayi dalam postingan yang ada di akuninstagran@parentalk.id.

Informan mengatakan bahwa:

"Ada beberapa video tutorial yang diposting, contohnya seperti tutorial pijat untuk bayi yang baru lahir. Video semacam ini berguna banget bagi kami yang memiliki bayi, namun belum mengetahui cara pijat yang benar. Selama ini kalau pijat selalu 
Vol 3No. 1, 2020, 23-36

DOI: $10.30596 /$ persepsi.v\%vi\% i.4428

mengandalkan bantuan tukang pijat bayi dan tidak efisien, melalui video postingan @ parentalk.id ini yah ibu-ibu bisa belajar untuk praktekkan sendiri pijat pada bayinya worth it banget"

Dari hasil wawancara pada informan, terlihat adanya respons behavioral dengan indikasi setelah followers mengetahui, kemudian tertarik dan menimbulkan suatu tindakan. Tindakan yang dimkasud adalah dimana followers mempraktekkan pengetahuannya dari postingan tersebut kepada pengala man dirinya dalam penanganan terhadap bayi mereka.

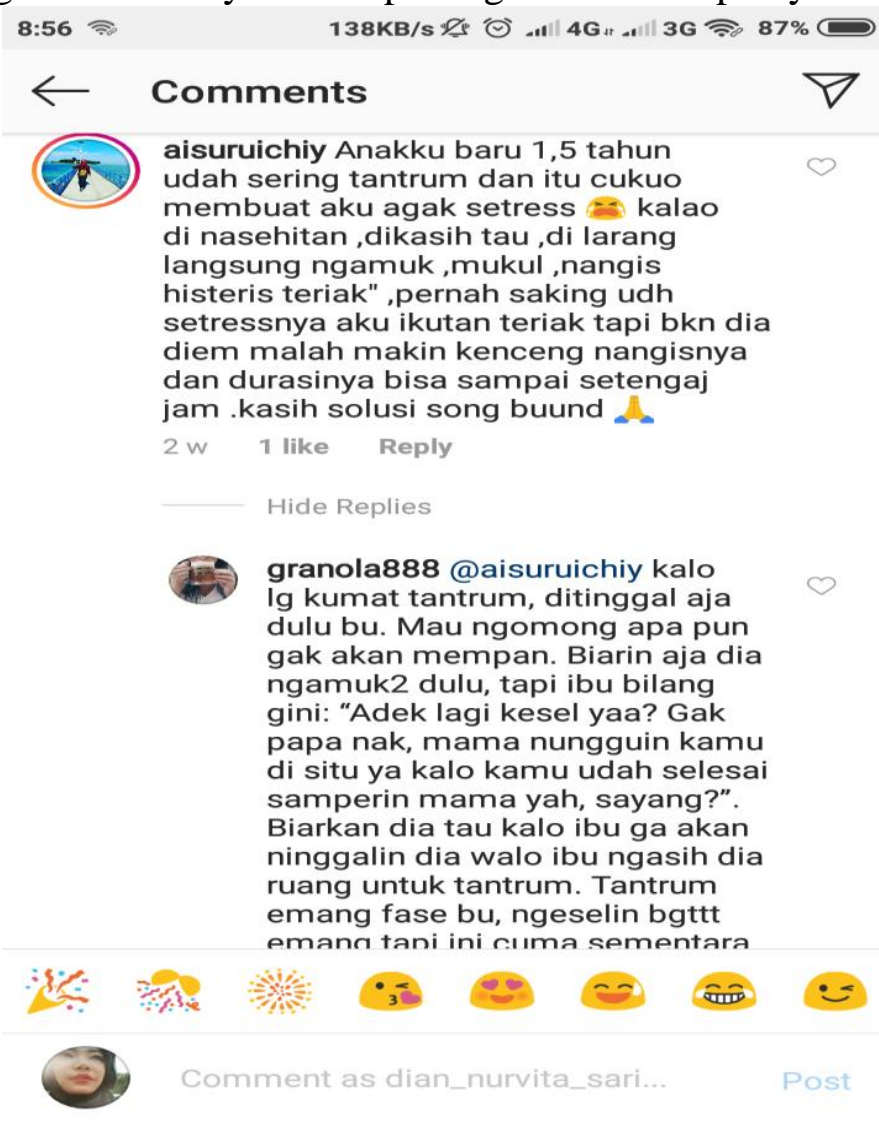

Gambar 5. Memuat kolom comment followers

Dari gambar 5 kita dapat melihat contoh lain dari respons behavioral yang terdapat pada followers akun instagram @ parentalk.id. Respons tersebut berupa komen dari follower yang memberikn pertanyaan kepada admin, kemudian dibalas oleh admin atau oleh followers lain yang memiliki pengalaman serupa dengan pertanyaan tersebut. Respon ini kemudian dikategorikan sebagai respons positif dari follower terhadap postingan dalam akun instagram tersebut. Bahkan beberapa followers menautkan akun followers lain atau istilahnya lebih dikenal dengan sebutan mentionsehingga followers lainnya dapat dengan mudah melihat postingan dari akun intagram @ parentalk.id ini. Biasanya followers akan menautkan akun followers lain karena dirasa informasinya berguna juga bagi followers lain yang ia mention.

Adanya kebutuhan informasi terkait edukasi parenting yang dimiliki oleh ibu muda menjadikan mereka sebagai followers aktif pada akun instagram @ parentalk.id. Selama ini mereka hanya mengandalkan pengalaman orang tua terdahulu sebagai referensi mereka dalam pengasuhan anak atau parenting. Admin melihat adanya peluang yang besar untuk menjadikan instagram sebagai media edukasi parenting mengingat kebutuhan akan informasi tersebut (Bin-Tahir et al. 2019). Para followers ternyata mengalami sikap atau emosi pada dirinya. Perubahan yang terjadi adalah mereka cukup memiliki keinginan untuk memberikan like kepada postingan akun intagram @ parentalk.id membaca postingan atau melihat video 
DOI: $10.30596 /$ persepsi.v\%vi\% i.4428

sehingga informasi dapat tersalurkan dengan baik. Penggunaan media sosial untuk menemukan dan menyebarkan informasi kesehatan dengan cepat meningkat di seluruh lapisan masyarakat (Schroeder 2017). Respons behavioral, respon ini telah pada tahap follower melakukan suatu tindakan setelah mendapatkan informasi dari postingan yang ada pada akun instagram @ parentalk.id. Tindakan yang dilakukan oleh follower bisa berupa menshare postingan tersebut kepada follower lain yang juga merupakan ibu muda yang membutuhkan informasi parenting. Respons behavioral positif juga ditandai dengan tindakan yang dapat dilakukan oleh followers setelah membaca atau melihat video yang di posting oleh admin dalam akun @ parentalk.id.

\section{KESIMPULAN}

Penulis menyimpulkan bahwa informasi edukasi parenting yang diposting melalui akun@ @arentalk.id berupa photo, video atau interaktif talk memiliki respons pos itif dari para followers yang merupakan ibu muda. Kehadiran akun Instagram @ parentalk.id menjadi media rujukan dalam pemenuhan kebutuhan informasi mengenai parenting bagi para ibu muda.Respon behavioral tersebut juga terlihat dengan adanya perubahan sikap followers dalam mengasuh anak-anak mereka sesuai dengan pengetahuan yang mereka dapatkan berupa informasi parenting.

\section{DAFTAR PUSTAKA}

Afrilia, Ascharisa Mettasatya. 2017. "Penggunaan New Media Di Kalangan Ibu Muda Sebagai Media Parenting Masa Kini.” Jurnal Komunikasi Dan Kajian Media 1(1).

Arindita, Ruvira. 2017. "Representas i Ibu Ideal Pada Media Sosial ( Ana lis is Multimodality Pada Akun Instagram." 6:131-47.

Asiodu, Ifeyinwa V., Catherine M. Waters, Dawn E. Dailey, Kathryn A. Lee, and Audrey Lyndon. 2015. "Breastfeeding and Use of Social Media among First-Time African American Mothers." Journal of Obstetric, Gynecologic \& Neonatal Nursing 44(2):268-278.

Baker, Sabine, Matthew R. Sanders, and Alina Morawska. 2017. "Who Uses Online Parenting Support? A Cross-Sectional Survey Exploring Australian Parents' Internet Use for Parenting." Journal of Child and Family Studies 26(3):916-27.

Bin-Tahir, Saidna Zulfiqar, Muhammad Amri, Andi Mukarramah Nagauleng, Amirah Diniaty, and Ibnu Hajar. 2019. "The Social Media Use For Digital Natives: Parenting Model Of Muslim Cleric Families." 8(11):5.

Celuch, Kevin, Stephen Goodwin, and Steven A. Taylor. 2007. "Understanding Small Scale Indus trial User Internet Purchase and Information Management Intentions: A Test of Two Attitude Models.” Industrial Marketing Management 36(1):109-20.

Churchill, Harriet, and Karen Clarke. 2010. "Investing in Parenting Education: A Critical Review of Policy and Provision in England." Social Policy and Society 9(1):39-53.

Duggan, Maeve, Amanda Lenhart, Cliff Lampe, and Nicole B. Ellis on. 2015. "Parents and Social Media." Pew Research Center 1-37. 
DOI: $10.30596 /$ persepsi.v\%vi\% i.4428

Erlanti, Mutiara Suci, and Nandang Mulyana. 2016. "Penerapan Teknik Parenting Di Rumah Parenting Yayasan Cahaya Insan Pratama Bandung." Prosiding Penelitian \& Pengabdian Kepada Masayarakat 3(2):155-291.

Gumilar, Gumgum, Ipit Zulfan, Fakultas Ilmu Komunikasi, and Universitas Padjadjaran. 2014. 'Penggunaan Media Massa Dan Internet Sebagai Sarana Penyampaian Informasi Dan Promosi Pengelola Industri Kecil Dan Menengah Di Bandung." Kajian Komunikasi V2(1 Jun 2014):85-92.

Haslam, Divna M., Ame lia Tee, and Sabine Baker. 2017. "The Use of Social Media as a Mechanism of Social Support in Parents." Journal of Child and Family Studies 26(7):2026-37.

Hu, Yuheng, Lydia Manikonda, and Subbarao Kambhampati. 2014. "What We Instagram : A First Analys is of Instagram Photo Content and User Types." Proceedings of ICWSM. AAAI. 4.

Huang, Yi Ting, and Sheng Fang Su. 2018. "Motives for Instagram Use and Topics of Interest among Young Adults.” Future Internet 10(8).

Jackson, Timothy J., Christine E. Stake, Youssef El Bitar, Dror Lindner, Itamar Botser, and Benjamin G. Domb. 2013. "Surgical Dis location of the Hip versus Arthroscopic Treatment of Femoro-Acetabular Impingment: A Prospective Comparative Study with 2-Year Follow-Up." Orthopaedic Journal of Sports Medicine 1(4).

Kim, Kyung Sun, Sei Ching Joanna Sin, and Yuqi He. 2013. "Information Seeking through Social Media: Impact of User Characteristics on Social Media Use." Proceedings of the ASIST Annual Meeting 50(1).

Kurniawan, Puguh. 2017. "Pemanfaatan Media Sosial Insta gram Sebagai Komunikasi Pemasaran Modern Pada Batik Burneh.” Jurnal Kompetensi 11(02):217-25.

Mehrad, Jafar, and Pegah Tajer. 2016. "Uses and Gratification Theory in Connection with Know ledge and Information Sc ience: A Proposed Conceptual Model." International Journal of Information Science and Management 14(2):1-14.

Mutmainah, S., and A. Fauzi. 2002. Psikologi Komunikasi. Jakarta: Universitas Terbuka.

Pittman, Matthew, and Brandon Reich. 2016. "Social Media and Loneliness: Why an Instagram Picture May Be Worth More than a Thousand Twitter Words." Computers in Human Behavior 62:155-167.

Røpke, Inge. 2009. "Theories of Practice-New Inspiration for Ecological Economic Studies on Consumption." Ecological Economics 68(10):2490-2497.

Sari Puspita, Meutia. 2017. "Fenomena Penggunan Media Sosial Insta gram Sebagai Komunikasi Pembe lajaran Agama Islam Oleh Mahasiswa Fisip Universitas.” Jumal Ilmiah Mahasiswa Fakultas Ilmu Sosial \& Ilmu Politik 4(2):1-13.

Schroeder, Wilma K. 2017. "Leveraging Social Media in \#FamilyNursing Practice." Journal of Family Nursing 23(1):55-72. 
PERSEPSI: Communication Journal

e-ISSN 2623-2669

Vol 3No. 1, 2020, 23-36

DOI: $10.30596 /$ persepsi.v\%vi\% i.4428

Simpson, A. Rae. 1997. "The Role of the Mass Media in Parenting Education."

Study, Breakup. 2006. "Journal of Broadcasting \& Electronic Media." Journal of Broadcasting \& Electronic Media (776102498):37-41. 